\title{
STUDI LITERATUR: ROBOTIC PROCESS AUTOMATION
}

\author{
Donny Fernando ${ }^{1}$, Harsiti ${ }^{2}$ \\ ${ }^{1,2}$ Jurusan Sistem Informasi Fakultas Teknologi Informasi Universitas Serang Raya \\ Jln. Raya Cilegon Serang - Drangong Kota Serang \\ ${ }^{1}$ mr.donny2008@gmail.com \\ ${ }^{2}$ harsiti@yahoo.com
}

\begin{abstract}
Abstrak - Robotic Process Automation (RPA) adalah bentuk teknologi otomatisasi proses bisnis yang bekerja mengotomasikan interaksi dengan desktop GUI pengguna akhir. RPA akan meniru aktivitas manusia di dalam komputer dengan waktu yang jauh lebih cepat dan akurasi 100\% tanpa "faktor manusia". Penelitian ini bertujuan untuk menyediakan sarana untuk memahami dan mendapatkan pemahaman tentang RPA. Dengan interaksi yang erat antara manusia dan robot, perusahaan akan dapat memberikan pelayanan yang lebih baik dan karyawan akan memiliki waktu lebih untuk mengerjakan yang lebih bernilai.
\end{abstract}

Kata kunci-Robotic Process Automation, RPA, Software Robot.

\section{PENDAhUluan}

Mendengar kata "robotika" tentu membawa kekhawatiran dan kegembiraan pada saat yang sama di masyarakat. Lonjakan usia produktif di Indonesia dan seiring bersamaan dengan buzzword revolusi Industri 4.0 hal ini juga menjadi perhatian dan kekhawatiran juga bagi pemerintah dan masyarakat. Seperti dikutip dari cnbcindonesia.com "Menteri Komunikasi dan Informatika Rudiantara menuturkan, revolusi industri 4.0 memang sebuah keniscayaan. Ia mengakui, memang dengan masuknya industri 4.0, itu ada pekerjaanpekerjaan yang digantikan dengan robot, dan berkurangnya lapangan pekerjaan."

Namun tak dapat dipungkiri bahwa robot akan menjadi rekan kerja kita. Setiap tugas berulang yang membutuhkan ketepatan dan kecepatan, namun sedikit penilaian, akan lebih baik dilakukan oleh robot.

Ketika manusia dipaksa untuk mengerjakan proses-proses manual dan membosankan secara berulang-ulang, hal itu dapat menyebabkan frustasi seiring berjalannya waktu dan menjadi rawan kesalahan. Berbeda dengan manusia, robot tidak memiliki perasaan sehingga robot akan tetap menghasilkan kualitas pekerjaan yang sama seiring dengan berjalannya waktu.

Hal ini mengingat pasar tenaga kerja saat ini memiliki sedikit karyawan dengan kemampuan-kemampuan yang mumpuni, mempekerjakan manusia untuk tugas-tugas berulang tersebut sama artinya dengan menyia-nyiakan sumber daya yang berharga.

Solusinya adalah Robotic Process Automation (RPA), menggunakan RPA perusahaan-perusahaan dapat mengotomasi banyak proses berulang, baik di front office dan back office sehingga dapat meningkatkan efisiensi dan efektivitas agar lebih kompetitif.

Menggunakan RPA, sebuah perusahaan dapat mengkonfigurasi perangkat lunak atau software "robot" untuk menangkap dan menafsirkan aplikasi untuk memproses transaksi, memanipulasi data, memicu respon dan berkomunikasi dengan sistem digital lainnya. RPA mampu mengerjakan pekerjaan berulang lebih cepat dan lebih akurat dibandingkan manusia.

Pada sebuah case study yang dikeluarkan oleh Infosys, implementasi RPA dapat menghasilkan penurunan Full Time Equivalent (FTE) sebesar 50\%, dan menurunkan pekerjaan manual sebesar 58\%. Aktivitas bot akan direkam dan disimpan dalam manajemen log yang tersedia, dan dari datadata tersebut dihasilkan analisa bahwa dengan robot dapat meningkatkan waktu proses mencapai $70 \%$.

RPA juga bersifat non-intrusif dan memanfaatkan infrastruktur yang ada tanpa menyebabkan gangguan pada sistem yang mendasarinya, yang akan sulit dan mahal untuk diganti. Dengan RPA, efisiensi biaya dan kepatuhan terhadap peraturan lisensi bukan lagi menjadi biaya yang membebani ketika akan mengimplementasikan sebuah integrasi antar sistem. 


\section{Metodologi Penelitian}

Penelitian ini menggunakan metode penelitian deskriptif, dimana penelitian ini mengumpulkan data secara detail dari berbagai literatur seperti jurnal ilmiah dan internet kemudian disampaikan kesimpulan yang mendalam secara sistematis dan juga actual. Adapun langkah-langkah yang digunakan adalah:

1. Studi literatur

Pada tahap ini dilakukan penggalian konsep penelitian melalui studi pustaka.

2. Observasi

Observasi dilakukan dengan pengamatan dari berbagai implementasi RPA yang dilakukan oleh perusahaan melalui berbagai sumber informasi yang didapatkan dari internet.

\section{HASIL DAN PEMBAHASAN}

\section{A. Apa itu RPA?}

Robotic Process Automation (RPA) adalah sebuah bentuk teknologi otomatisasi proses bisnis yang bekerja mengotomasikan interaksi dengan desktop GUI pengguna akhir.

Robotic Process Automation (RPA) merupakan sebuah software robot. Software robot yang digunakan untuk melakukan task komputer yang terstruktur, rutin, berulang dan akan menjadi lebih optimal pemanfaatannya jika dilakukan dalam volume yang besar. RPA adalah sebuah teknologi baru yang potensinya masih belum direalisasi secara seutuhnya.

Dengan robot atau dikenal juga dengan istilah bot, akan meniru aktivitas manusia di dalam komputer dan mengerjakannya seperti apa yang dilakukan oleh manusia dengan waktu yang jauh lebih cepat dan akurasi 100\%. Robot juga dapat bekerja 24 jam sehari dan 7 hari dalam satu minggu tanpa lelah dan berkurang kemampuannya.

Robot tersebut memungkinkan anda untuk mereplikasi bagaimana orang melakukan tugas yang berulang dalam suatu aplikasi (misalkan: memasukkan data, melakukan tugas yang berhubungan dengan transaksi).

Namun RPA bukan ada untuk menggantikan peran manusia di dalam industri atau perusahaan, tetapi RPA bertujuan untuk meningkatkan outcome dari karyawan, sehingga robot akan menjadi asisten yang efektif dan powerfull.

\section{B. Perbedaan RPA dengan Otomasi Tradisional}

RPA terkadang disebut juga dengan robotic digital workplace. Bagi sebagian orang yang belum memahami perbedaan RPA dengan tradisional otomasi terkadang hal ini membuat kebingungan dan salah memahami apa yang dimaksud dengan proses otomasi yang dimaksudkan oleh RPA tersebut.

Otomasi tradisional adalah memerlukan integrasi aplikasi pada tingkat basis data atau infrastruktur dan hal tersebut dapat memakan waktu berbulan-bulan untuk diimplementasikan. Sedangkan RPA adalah bentuk otomatisasi lainnya, dan memiliki beberapa fitur yang membedakan seperti sebagai berikut:

1. RPA bersifat non-intrusif (tidak mengganggu). RPA tetap berada di front end sistem dan tidak mengganggu back end sistem.

2. RPA bersifat agnostic atau bekerja lintas tipe aplikasi.

3. RPA mampu mengambil tindakan dengan cepat karena kemampuannya untuk meniru peran manusia.

4. RPA memiliki sifat yang scalable, sehingga mudah untuk menangani penambahan beban kerja yang dibutuhkan serta mudah di integrasikan.

5. RPA dikembangkan untuk mempermudah bagi orang-orang non-teknis untuk menggunakan. Di desain tanpa kode programming sehingga mudah untuk dipelajari.

Mungkin yang paling penting dari semuanya, RPA sangat cepat diimplementasikan, dibandingkan dengan otomatisasi tradisional, yang dapat memakan waktu beberapa bulan. Juga, tidak seperti otomatisasi tradisional, RPA tidak memerlukan integrasi aplikasi, karena RPA menggunakan Users Interface (UI) GUI untuk melakukan tugasnya di berbagai sistem.

RPA adalah solusi perbaikan cepat jika dibandingkan dengan otomatisasi tradisional, RPA dapat diimplementasikan dalam hitungan minggu, sementara otomasi tradisional membutuhkan waktu berbulan-bulan. Kadang-kadang RPA dapat digunakan dalam jangka pendek, sampai proyek otomatisasi tradisional dapat direncanakan dan diimplementasikan. Dan terkadang, RPA adalah solusi terbaik untuk integrasi yang membutuhkan akses ke beberapa aplikasi. RPA juga sangat berguna ketika mengotomatisasi aplikasi legacy yang tidak menyediakan API mereka sendiri.

Salah satu fitur yang membedakan RPA adalah kemampuannya untuk menghubungkan sistem yang tidak dapat dengan mudah diotomatisasi melalui pendekatan otomasi tradisional. Dengan RPA tidak diperlukan High Level Integration.

Namun apakah otomasi tradisional akan hilang? Jawabannya tentulah tidak, karena otomasi tradisional berbasis API tetap diperlukan. Kemampuan otomatisasi tradisional untuk memindahkan sejumlah besar data, dengan cepat, antar sistem tetap tak tertandingi. RPA hanya bekerja pada bagian Users Interface (UI) pengguna.

\section{Type Robotic Process Automation (RPA)}


RPA dapat bekerja dalam 2 tipe mode yaitu attended mode dan unattended mode. Bot dengan mode attended akan membutuhkan manusia untuk menjalankannya, sedangkan robot dengan mode unattended dapat dijadwalkan atau dapat dijalankan dari sebuat event.

Unattended bot biasanya melakukan operasi batch yang tidak memerlukan intervensi pengguna. Misalnya, kumpulan informasi klien baru diterima dalam spreadsheet dan perlu dimasukkan ke beberapa aplikasi.

Perusahaan yang mengharapkan efektivitas RPA dalam alur kerjanya pertama-tama perlu memahami perbedaan antara Attended Bot dan Unattended Bot.

Attended bot biasanya berjalan di local desktop, artinya mereka memanipulasi program front-office yang sama dengan yang digunakan oleh pengguna akhir. Ini kadang-kadang disebut juga sebagai otomasi desktop. Attended bot merespons secara eksklusif terhadap permintaan pengguna atau peristiwa yang dipicu manusia. Dengan kata lain attended robot dapat juga disebut sebagai asisten pribadi pengguna akhir.

Attended bot bermanfaat untuk pengguna agar dapat dengan cepat mengkoordinasikan tugas-tugas sederhana namun membosankan seperti mencari dan mengambil data pelanggan tertentu. Misalnya, attended bot dapat mengambil data dari satu aplikasi dan membawanya ke aplikasi yang lain.

Secara umum ada 3 manfaat utama yang didapatkan jika mengimplementasi attended bot yaitu:

1. Waktu implementasi yang cepat.

2. Pengembalian investasi yang cepat.

3. Tidak mengganggu alur kerja yang ada.

Unattended bot digunakan untuk fungsi back-office yang memiliki dampak yang lebih luas pada alur kerja. Unattended bot biasanya berjalan di server organisasi dengan sedikit atau tanpa campur tangan manusia. Unattended bot akan berjalan pada jadwal yang telah ditentukan atau secara real time, 24/7/365.

Berikut dibawah ini adalah contoh skenario RPA yang menggunakan mode Unattended bot sbb:

1. Pemrosesan klaim di perusahaan asuransi.

2. Pemrosesan aplikasi untuk pelanggan membuka rekening di bank.

3. Pembuatan dan distribusi faktur dari pemasok.

Tidak seperti attended bot, unattended bot dapat dikendalikan dan dijadwalkan dari jarak jauh karena mereka biasanya beroperasi pada mesin virtual. Keterlibatan TI mungkin diperlukan untuk konfigurasi unattended bot.

Secara umum ada 3 manfaat utama yang didapatkan jika mengimplementasi unattended bot yaitu:

1. Transformasi digital adalah keunggulan utama unattended bot.

2. Mengoptimalkan proses di seluruh perusahaan.

3. Memiliki potensi ROI yang lebih besar.

\section{Pekerjaan apa yang dapat dilakukan oleh software robot?}

Bot dapat melakukan banyak aktivitas seperti yang dilakukan manusia, namun pertanyaannya "apakah semua aktivitas manusia dapat dilakukan oleh robot?". Pertanyaan ini sering ditanyakan.

Atas pertanyaan tersebut diatas sebenarnya yang perlu diketahui bahwa ada 6 aktivitas yang pada umumnya dapat dilakukan bot pada terminal pengguna akhir diantaranya adalah:

1. Aktivitas data entry.

2. Aktivitas copy \& paste.

3. Aktivitas mouse selection.

4. Aktivitas screen navigation.

5. Aktivitas Login dan Logout aplikasi.

6. Aktivitas Web Services Invocation \& DB Query.

\section{E. Manfaat RPA bagi perusahaan.}

RPA bekerja paling baik dengan tugas reguler berbasis aturan dan membutuhkan input manual. Pendekatan RPA adalah untuk merampingkan proses internal.

Menurut Prof Leslie Willcocks, Professor of Technology Work and Globalization and governor of the Information Systems and Innovation Group at the London School of Economics, dari hasil penelitiannya yang disajikan di laporan penelitian McKinsey, disampaikan bahwa Return of Investment (ROI) implementasi RPA di perusahaan bervariasi berkisar antara $30 \%$ sampai dengan $200 \%$ pada tahun pertamanya.

Namun Prof Leslie Willcocks menyampaikan bahwa adalah salah untuk berpikir bahwa mengimplementasi RPA ditujukan untuk mencapai manfaat jangka pendek. Ada beberapa manfaat atau keuntungan yang akan didapatkan perusahaan setelah mengimplementasikan RPA yaitu:

1. Reduce Cost: dengan mengotomasi tugas-tugas rutin karyawan, RPA akan mencapai penghematan biaya operasional mencapai $30 \%$ diatas output produktivitas yang dihasilkan karyawan. Software robot harganya juga lebih murah dibandingkan karyawan yang bekerja full time.

2. Better customer experiences: dengan mengimplementasikan RPA akan memberikan manfaat nyata bagi sumber daya perusahaan untuk tetap fokus pada kepuasan pelanggan.

3. Lower operational risk: RPA akan membantu perusahaan untuk menurunkan resiko human error yang terjadi karena kurangnya pengetahuan dalam mengoperasikan sistem.

4. Improved internal processes: RPA akan membantu perusahaan untuk meningkatkan proses pelaporan menjadi lebih cepat, onboarding employee lebih cepat dan kegiatan internal lainnya. Dengan meningkatkan kemampuan robot melalui Artificial 
Intelligence (AI) dan Machine Learning (ML) maka perusahaan akan dipaksa untuk mendefinisikan prosedur tata kelolanya dengan jelas.

5. Productivity: dibandingkan dengan manusia robot dapat menyelesaikan pekerjaannya $5 \mathrm{x}$ lebih cepat dibandingkan manusia. Robot bekerja 24/7, tidak ada cuti, sakit ataupun tidak dapat masuk karena berbagai alasan.

6. RPA tidak menggantikan sistem IT legacy yang berjalan saat ini, namun dengan RPA akan meningkatkan sistem IT yang ada.

\section{F. Studi Kasus RPA}

Setiap industri (mis. Telekomunikasi, layanan keuangan, dll.) Dan fungsi bisnis (mis. Pemasaran, penjualan, dll.) Memiliki proses yang berbeda. Jadi tidak mudah untuk mendapatkan daftar proses yang diotomatisasi untuk fungsi industri dan bisnis yang spesifik.

Bank, lembaga keuangan, dan perusahaan asuransi memproses sejumlah besar operasi setiap hari. Di sektor yang membutuhkan operasi intensif dan besar, RPA dapat digunakan sebagai pekerja virtual, menggantikan manusia dalam tugas-tugas harian dan berulang. RPA memungkinkan bank-bank modern untuk memenuhi tuntutan tinggi mereka akan kemampuan menangkap informasi, keamanan, dan kualitas data, sementara juga meningkatkan efisiensi operasional. Dalam aplikasi kartu kredit, RPA digunakan untuk menangani tugas-tugas seperti menerbitkan kartu kepada pengguna. RPA meningkatkan kecepatan dan akurasi tugas, yang pada gilirannya meningkatkan produktivitas.

Berdasarkan laporan dari McKinsey beberapa aktivitas di sektor asuransi dapat di otomasi seperti:

1. Sales Process

2. Underwriting

3. Update informasi yang terkait dengan policy asuransi seperti informasi bank.

4. Reject dan cancel policy jika pembayaran tidak diterima

5. Claim proses.

6. Otomasi rekonsiliasi data finance.

Pada industri ritel adalah salah satu industri yang sangat diuntungkan dari penggunaan RPA. RPA dirancang untuk menangani akun penipuan, misalnya, serta untuk memperbarui pesanan dan memproses pemberitahuan pengiriman, sehingga menghilangkan kebutuhan untuk secara manual melacak barang yang dikirim.

Sedangkan pada industri telekomunikasi, RPA digunakan untuk memantau feedback pelanggan CRM, data manajemen penipuan, dan pembaruan data pelanggan. RPA juga bertindak sebagai middleware untuk mengotomatisasi informasi pengguna.

Pada manufacturing, pemanfaatan RPA dapat memperkuat prosedur supply chain, menjembatani kesenjangan antara kegiatan berulang seperti mengutip, membuat faktur, utang dagang, piutang, general ledger dan lain-lain.

\section{G. Otomasi ERP dengan RPA}

Robotic Process Automation (RPA) membantu dalam meningkatkan kinerja sistem Enterprise Resource Planning (ERP).

Banyak aplikasi ERP perusahaan, termasuk platform SAP dan Oracle ERP, membutuhkan banyak pekerjaan manual dan berulang - pekerjaan yang dapat menguras semangat, menurunkan produktivitas, dan menemukan banyak kesalahan data. Dengan menggunakan RPA yang dilakukan dengan benar memungkinkan karyawan untuk mengerjakan tugastugas yang bernilai lebih tinggi dan membuat dampak nyata pada bisnis.

Pemanfaatan RPA yang tepat dapat secara dramatis meningkatkan produktivitas dan kualitas data - membantu organisasi bergerak lebih dekat ke perusahaan digital di masa depan.

Berikut di bawah ini contoh skenario implementasi RPA dapat dilihat pada gambar G.1 :

1. Bot RPA menerima email dengan formulir permintaan faktur excel standar.

2. Bot masuk ke perangkat lunak perencanaan sumber daya perusahaan SAP.

3. Ekstrak data dari excel dan memasukkannya ke dalam SAP.

4. Membuat faktur dalam SAP dan mengirimkannya ke pemohon.

5. Bot mengirim email konfirmasi, menunjukkan bahwa faktur telah dibuat dan dikirim.

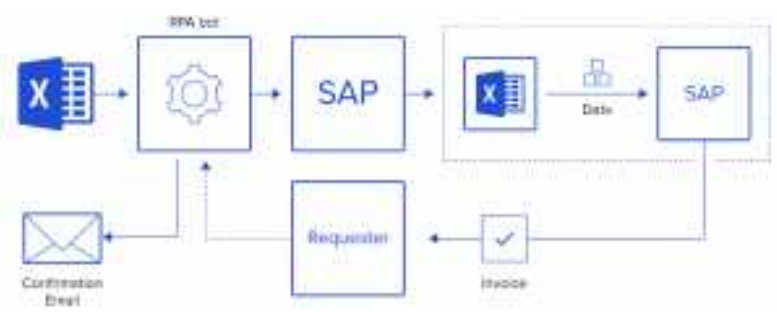

Gb. G.1. Skenario RPA dengan ERP

Untuk memastikan hasil sesuai yang diharapkan ada beberapa langkah yang perlu diperhatikan perusahaan sebelum mengadopsi RPA untuk membantu sistem ERP perusahaan diantaranya adalah:

1. Tidak ada RPA tools yang dapat memenuhi semua kebutuhan perusahaan untuk otomatisasi.

2. Menerapkan pilot proyek implementasi RPA untuk ruang lingkup yang terbatas untuk membuktikan ROI dan efektivitas sebelum meningkatkannya. 
3. Bisnis users berada di posisi yang seharusnya untuk berperan aktif mengotomatisasi proses mereka dan menyelesaikan masalah.

\section{H. Bagaimana mengimplementasikan RPA?}

Banyak perusahaan melihat cost saving dan efficiency merupakan manfaat dari penerapan solusi RPA. Namun untuk mencapai tujuan tersebut ditemukan beberapa tantangan yang akan dan mungkin terjadi diantaranya:

1. Tidak mengetahui dari mana akan memulai adopsi RPA

2. Setelah organisasi meluncurkan proyek percontohan yang sukses, kesuksesan mungkin tidak terbawa ke proyek berikutnya, karena setiap proses membawa tantangannya sendiri.

3. Waktu implementasi yang panjang karena scope implementasi yang terlalu luas.

Untuk menjawab tantangan diatas, berikut adalah 12 langkah yang dapat dilakukan untuk memastikan adopsi teknologi RPA ini memberikan hasil sesuai harapan pemangku kepentingan diantaranya sbb:

1. Untuk memaksimalkan dampak RPA, identifikasi proses yang akan menghasilkan manfaat terbesar saat diotomatisasi.

2. Pilih proses yang berdampak besar dapat dengan mudah diotomatisasi dengan RPA. Berikut di bawah ini adalah proses-proses yang memiliki dampak terhadap adopsi RPA sebagai berikut:
a. Berdampak terhadap cost atau revenue
b. Volume pekerjaan yang tinggi
c. Toleransi kesalahan yang rendah
d. Waktu menyelesaikan pekerjaan
e. Membutuhkan tenaga kerja yang tidak teratur.

3. Dapatkan dukungan manajemen puncak perusahaan.

4. Dapatkan dukungan tim.

5. Memastikan semua pemangku kepentingan telah memahami maksud dan tujuan adopsi RPA

6. Perbaiki proses

7. Pilih partner yang bertindak sebagai RPA provider.

8. Kembangkan solusi

9. Test Solusi

10. Jalankan pilot proyek

11. Go Live

12. Pemeliharaan RPA

Ketika mengadopsi RPA, perusahaan perlu memperhatikan 3 hal di bawah ini yang dapat menjadi rintangan ketika mengadopsi teknologi RPA yaitu:

1. Kurangnya komitmen baik dari manajemen atau tim itu sendiri sehingga dapat menunda proyek apa pun dan proyek RPA tidak terkecuali.
2. Memilih proses yang terlalu rumit atau tidak signifikan akan menyebabkan dampak yang terbatas. Misalnya, menerapkan RPA ke bidang seperti audit biaya di mana solusi khusus ada, dapat mengarah pada upaya signifikan tanpa hasil yang memuaskan.

3. Memilih tools RPA yang sulit digunakan sehingga hal tersebut dapat memperlambat upaya pengembangan.

\section{Tingkat kematangan organisasi dalam implementasi RPA}

Menurut Leslie Willcocks ada 4 tingkat kematangan organisasi dalam mengimplementasikan RPA yaitu:

1. Level 1 yaitu disebut Personal Assistant Bots. Pada level ini karyawan atau pengguna akhir dapat mendelegasikan pekerjaan administratif yang dilakukan kepada robot.

2. Level 2 yaitu disebut Personal Multiplication Bots. Pada level ini RPA sudah berjalan dan sudah ada beberapa proses yang berbeda dilakukan otomasi dan organisasi telah mengerti proses mana yang dapat di otomasi menggunakan RPA.

3. Level 3 yaitu disebut Organization Scaling. Pada level ini, seluruh fungsi dapat diotomatisasi, Dan pemanfaatan RPA bukan lagi akan paralel dengan proses kerja di area desktop pengguna.

4. Level 4 yaitu disebut Innovation Enablement. Pada level ini transformasi digital tidak lagi terhambat oleh opsi integrasi sistem.

\section{KESIMPULAN}

Berdasarkan hasil penelitian dan pembahasan akhirnya dapat disimpulkan bahwa Robotic Process Automation (RPA) adalah sebuah revolusi teknologi otomasi yang dapat meningkatkan daya saing perusahaan. Namun untuk mendapatkan manfaat maksimal adopsi teknologi RPA ini perlu desain dan perencanaan yang baik.

Dapat disimpulkan beberapa faktor sukses adopsi RPA pada sebuah organisasi yaitu:

1. Strategi RPA

2. Sumber daya manusia

3. Partner implementasi RPA

4. Proses yang matang, didefinisikan, dan berulangulang

5. Project Management

6. Teknologi RPA yang digunakan

7. Keterlibatan IT

\section{UCAPAN TERIMA KASIH}

Terima kasih saya ucapkan kepada semua pihak yang telah membantu dalam menyelesaikan penelitian ini. Semoga penelitian ini dapat bermanfaat untuk semua pihak yang 
sedang mempelajari dan mendapatkan informasi lebih jauh mengenai Robotic Process Automation (RPA) ini.

Tak lupa juga disampaikan tentunya penelitian kami ini jauh dari sempurna, sehingga saran dan kritik dari pembaca kami harapkan untuk penyempurnaan.

\section{REFERENSI}

[1] Mary C. Lacity, Leslie P Willcooks, (2016), a new approach to automating services.

[2] Leslie P Willcooks, Mary C. Lacity, Andrew Craig, (2015), Robotic Process Automation at Xchanging.

[3] Xavier Lhuer, (2016), https://www.mckinsey.com/business-functions/digitalmckinsey/our-insights/the-next-acronym-you-need-toknow-about-rpa.

[4] Michael Belfiore (2014), When robot take our jobs, human will be the new $1 \%$. Here how to fight back. The Guardian.

[5] Jhon Willey, (2018), Robotic Process Automation for Dummies.

[6] Anastasia Arvirianty, CNBC Indonesia, 2019, Revolusi Industri 4.0 Andalkan Robot, Begini Nasib Pekerja RI https://www.cnbcindonesia.com/news/201901200852474-51476/revolusi-industri-40-andalkan-robot-begininasib-pekerja-ri.

[7] Chris Lamberton, Damiano Brigo, Dave Hoy, (2016), Impact of Robotics, RPA and AI on insurance industry, challenges and opportunities.

[8] McKinsey, (2017), The value of robotic process automation. 